\title{
Cultivated and native browse legumes as calf supplements in Ethiopia
}

\author{
D. LAYNE COPPOCK AND JESS D. REED
}

\begin{abstract}
At the time of research, authors were staff scientists, International Livestock Center for Africa (ILCA), P.O. Box 5689, Addis Ababa, Ethiopia. D.L. Coppock is currently assistant professor, Department of Range Science, College of Natural Resources, Utah State University, Logan 84322-5230. J. D. Reed is currently an assistant professor with joint appointments to the Departments of Meat and Animal Science and Dairy Science, University of Wisconsin, Madison 53706.
\end{abstract}

\section{Abstract}

Efficient use of roughages is important for calf management in the Boran pastoral system. Using local legumes as protein supplements may improve fiber utilization and thus be an appropriate intervention. Fruits (pods and seeds) of Acacia tortilis (Forsk.) Hayne subsp. spirocarpa (Hochst. ex A. Rich) Brenan, leaves of $A$. brevispica (Harms), and cowpea [Vigna unguiculata (L.) Walp] hay were compared with alfalfa (Medicago sativa L.) hay as protein supplements for calves using 2 approaches. Sheep fed native grass hay under confinement were used for a controlled evaluation in growth and metabolism trials. Calves grazing dry-season forage under simulated pastoral management provided an evaluation under field conditions. All supplements increased $(P<0.05)$ nitrogen (N) intake, growth rate, and conversion of dry-matter intake into liveweight for sheep compared to unsupplemented animals. Calf growth and water intake were increased $(P<0.05)$ relative to the control by all supplements except cowpea hay. When statistically adjusted to a common level of $\mathbf{N}$ intake, $\mathbf{N}$ retention was similar $(P>0.05)$ among all groups of supplemented sheep. Compared to alfalfa and cowpea diets, tanniniferous $A$ cacia diets had a negative effect $(P<0.05)$ on true-N digestibility, but this was offset by their positive effect $(P<0.05)$ on reducing loss of urinary $N$. The $A$. tortilis diet had a lower $(P<0.05)$ true-N digestibility than the $A$. brevispica diet, which was probably influenced by soluble phenolics in pods and seeds. On a nutritional basis these Acacia and cowpea materials are suitable for inclusion in improved feeding systems for Boran calves.

Key Words: Acacia tortilis, A cacia brevispica, Vigna unguiculata, nitrogen supplementation, sheep nutrition, pastoralism

\footnotetext{
Research was funded by ILCA. The authors thank Belete Dessalegn for trial supervision and Alemayehu Demissie, Eshetu Zerihun, and other ILCA support staff for trial implementation. Mesfin Shibre, E.W. Richardson, and J. Sherington assisted with statistical analyses. The Southern Rangelands Development Unit (SORDU) of the Ethiopian Third Livestock Development Project (TLDP) gave permission to use Demballa Wachu ranch for the calf trial. Assistance from CARE-Ethiopia with calf procurement is also appreciated.

Manuscript accepted 6 August 1991
}

Livestock production in Africa's rangelands is limited by poor nutrition during dry periods. The problem can be most acute for nursing stock that compete with people for milk and have limited opportunity to forage (Donaldson 1986). Nutritional interventions for young animals may reduce the incidence of mortality and morbidity. In contrast to highlands systems where exotic forages are more easily established (Jahnke 1982), sustainable forage interventions in the rangelands depend to a higher degree on improved use of promising indigenous plants. Native woody vegetation can stabilize seasonal forage supplies (Coppock et al $1986 a, b)$ and traditional cultivated legumes can improve soil fertility (Hulet and Gosseye 1986), but little is known about their feeding value for livestock. Browse forage also contains tannins which interfere with nutrient utilization (Reed 1986, Robbins et al. 1987).

This study investigated the nutritive value of 3 important native forages in southern Ethiopia ( 2 browses and 1 cultivated legume) for possible inclusion in improved feeding systems for calves managed by seminomadic pastoralists. These materials were compared with alfalfa (Medicago sativa L.) as protein supplements for dryseason diets.

\section{Materials and Methods}

\section{Study Sites}

The target area for this research is the Borana Plateau (1,000 to 1,600-m elevation) of southern Ethiopia. The climate is semiarid with an annual bimodal rainfall of $600 \mathrm{~mm}$ largely received in April to May $(60 \%)$ and October to November (30\%). Plant communities consist of perennial grasses (Themeda Forsk., Cenchrus L., Pennisetum L. Rich., Chloris Sw. and Cynodon Rich. spp.) and trees (Acacia L., Commiphora Jacq., Combretum Loefl. and Terminalia L. spp.). The Boran pastoralists are seminomadic and primarily herd cattle (Cossins and Upton 1987).

A calf growth trial under simulated pastoral management was conducted during 1988 at Demballa Wachu ranch $(11,000$ ha at 
Table 1. Chemical characteristics (\% on a dry-matter basis) of basal diets and legume supplements for sheep and calf feeding trials in Ethiopial.

\begin{tabular}{|c|c|c|c|c|c|c|c|c|c|c|}
\hline & \multicolumn{10}{|c|}{ Forage } \\
\hline & $\begin{array}{c}\text { Basal } \\
\text { hay } \\
\text { sheep }\end{array}$ & $\begin{array}{l}\text { Basal } \\
\text { grazing } \\
\text { calves }\end{array}$ & \multicolumn{2}{|c|}{ Alfalfa hay } & \multicolumn{2}{|c|}{ Cowpea hay } & \multicolumn{2}{|c|}{ A. brevispica leaves } & \multicolumn{2}{|c|}{ A. tortilis fruits } \\
\hline & & & & & & - & $\cdots$ & 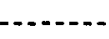 & $\cdots$ & 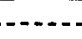 \\
\hline Dry matter & 92.4 & 91.3 & 91.3 & 88.5 & 91.3 & 89.7 & 91.4 & 89.2 & 91.4 & 88.1 \\
\hline Organic matter & 88.5 & 89.4 & 91.3 & 87.3 & 92.6 & 90.4 & 92.4 & 92.4 & 95.0 & 94.7 \\
\hline Nitrogen & 1.0 & 1.0 & 2.1 & 3.4 & 1.8 & 2.1 & 3.0 & 2.7 & 2.3 & 2.4 \\
\hline Neutral detergent fiber & 65.5 & 72.7 & 50.2 & 42.0 & 48.0 & 51.6 & 38.3 & 43.4 & 31.3 & 41.6 \\
\hline Acid detergent fiber & 38.9 & 44.3 & 41.5 & 30.9 & 39.1 & 46.4 & 25.7 & 26.2 & 24.6 & 31.5 \\
\hline Acid detergent lignin & 6.8 & 8.5 & 8.7 & 5.7 & 7.0 & 11.6 & 13.6 & 13.6 & 5.8 & 8.8 \\
\hline IVDMD $^{2}$ & 54.7 & 37.5 & 55.9 & 65.6 & 62.3 & 61.6 & 58.5 & 56.7 & 67.9 & 59.0 \\
\hline NDF-Nitrogen & 0.53 & 0.36 & 0.49 & 0.72 & 0.31 & 0.39 & 0.97 & 1.27 & 0.25 & 0.39 \\
\hline Soluble phenolics & 3.7 & 3.4 & 6.0 & 7.7 & 6.8 & 5.2 & 16.8 & 16.5 & 40.6 & 15.4 \\
\hline Insoluble proanthocyanidins ${ }^{3}$ & 0.07 & 0.03 & 0.02 & 0.03 & 0.03 & 0.02 & 0.31 & 0.40 & 0.06 & 0.12 \\
\hline
\end{tabular}

'Each tabulated entry represents the mean of 2 samples from a well-mixed feed source.

${ }^{2}$ Apparent in vitro dry-matter digestibility.

${ }^{3} \mathrm{Abs}$ orbance values per $\mathrm{g} D \mathrm{DM}$ of NDF at $550 \mathrm{~nm}$.

1,550 -m elevation). This is a government-managed ranch on the Borana Plateau $610 \mathrm{~km}$ south of Addis Ababa. Our research herd occupied the far southwest corner of the ranch at a stocking rate of 6 ha per Tropical Livestock Unit (TLU; 1 TLU $=250 \mathrm{~kg}$ liveweight; Jahnke 1982), similar to that of adjacent areas used by the pastoralists (Cossins and Upton 1987). Growth and metabolism trials for sheep in confinement were conducted during 1987 at an experiment station at Debre Zeit (1,800-m elevation), about $50 \mathrm{~km}$ southeast of Addis Ababa in the highlands.

\section{Forages \\ Basal Diets}

Mixed grass hay (Hyparrhenia Fourn., Andropogon L., and Pennisetum spp.) was prepared during the dry season in the highlands and was the basal diet component for the sheep. Hay was chopped to a $25-\mathrm{cm}$ length prior to feeding. The basal diet for the calves consisted of dry-season grazing on Pennisetum mezianum Leeke rangeland and milk from restricted suckling (described below).

\section{Supplements}

Acacia tortilis (Forsk.) Hayne subsp. spirocarpa (Hochst. ex A. Rich) Brenan is a common African tree traditionally used by livestock and humans for its production of dry, dehiscent fruits (Pratt and Gwynne 1977, Coughenour et al. 1985). Fruits (pods with seeds) were collected from trees in the Rift Valley (180-km south of Addis Ababa at 1,650-m elevation) for the sheep trials and on the Borana Plateau for the calf trial. Fruits were air dried in the shade and fed whole.

Acacia brevispica (Harms) is an important browse shrub for livestock in southern Ethiopia (Woodward 1988). It has large leaves ( 3 to $9 \mathrm{~cm}$ ) with good palatablity, and may remain green all year under favorable soil-moisture conditions. Leaves were harvested in June after the long rainy season on the Borana Plateau. Leaves were hand-plucked, air dried in the shade, and fed whole.

Vigna unguiculata (L.) Walp. or cowpea is an annual legume cultivated in semiarid Africa (Hulet and Gosseye 1986). Yields of 8.1 metric tons of dry matter (DM) per hectare have been reported on the Borana Plateau (Yohannes 1989). Cowpea was grown at Debre Zeit for the sheep trials and on the Borana Plateau for the calf trial. Plants were harvested at fruiting with the leaf and stem fodder separated out, air dried in the shade, and chopped to 25-cm lengths before feeding.

Alfalfa was grown at Debre Zeit for the sheep trials and nearby Modjo for the calf trial. It was harvested at about 50\% flowering, baled after sun drying, and chopped to $25-\mathrm{cm}$ lengths before feeding.

Table 2. Dietary intake (dry-matter basis) and performance of growing sheep $(n=6$ per treatment) fed native grass hay with or without $A$ cacia, cowpea or alfalfa supplements during an 84-day growth trial.

\begin{tabular}{|c|c|c|c|c|c|c|}
\hline \multirow[b]{2}{*}{ Diets } & \multicolumn{4}{|c|}{ Intake } & \multirow[b]{2}{*}{ Growth rate } & \multirow{2}{*}{$\begin{array}{l}\text { Diet conversion } \\
\text { efficiency }\end{array}$} \\
\hline & Supplement & Grass hay & Total diet & Nitrogen & & \\
\hline & $\ldots \ldots$ & $\cdots(g \cdot h$ & $\left.a y^{-1}\right) \ldots$. & $\ldots \ldots$ & $\left(\mathrm{g} \cdot \mathrm{head}^{-1} \cdot \mathrm{day}^{-1}\right)$ & $(\%)$ \\
\hline Grass hay & 0 & 624 & 624 & 6.2 & 31 & 4.9 \\
\hline \multicolumn{7}{|l|}{ Grass hay plus: } \\
\hline Alfalfa hay & 278 & 447 & 725 & 10.3 & 53 & 7.4 \\
\hline Cowpea hay & 312 & 427 & 739 & 9.9 & 57 & 7.6 \\
\hline A. brevispica leaves & 215 & 486 & 701 & 11.3 & 53 & 7.6 \\
\hline A. tortilis fruits & 307 & 384 & 691 & 10.9 & 53 & 7.6 \\
\hline SEM $^{2}$ & - & 28.9 & 29.1 & 0.32 & 4.2 & 0.54 \\
\hline \multicolumn{7}{|l|}{$F$-test probability3: } \\
\hline Overall & - & ** & NS & ** & $* *$ & ** \\
\hline Contrast 1 & - & ** & $*$ & $* *$ & $* *$ & $* *$ \\
\hline Contrast 2 & - & NS & NS & NS & NS & NS \\
\hline Contrast 3 & - & NS & NS & $* *$ & NS & NS \\
\hline Contrast 4 & - & $*$ & NS & NS & NS & NS \\
\hline
\end{tabular}

*;**Significant at the 0.05 and 0.01 levels, respectively.

'Diet conversion efficiency expressed as ( $\mathrm{g}$ average daily gain in liveweight/ $\mathrm{g}$ average daily dry-matter intake) $\times 100$.

2SEM = standard error of the means based on 25 degrees of freedom.

${ }^{3}$ Contrast $1=$ grass hay alone vs. supplemented diets; contrast $2=$ alfalfa diet vs. diets with the 3 indigenous supplements; contrast $3=$ alfalfa and cowpea diets vs. Acacia diets; and contrast $4=$ A. brevispica diet vs. A. tortilis diet. 
Table 3. Intake and digestibility of dry matter, organic matter and neutral detergent fiber by growing sheep (n=6 per treatment) fed native grass hay with or without $A$ cacia, cowpea or alfalifa supplements during a 10-day metabolism trial.

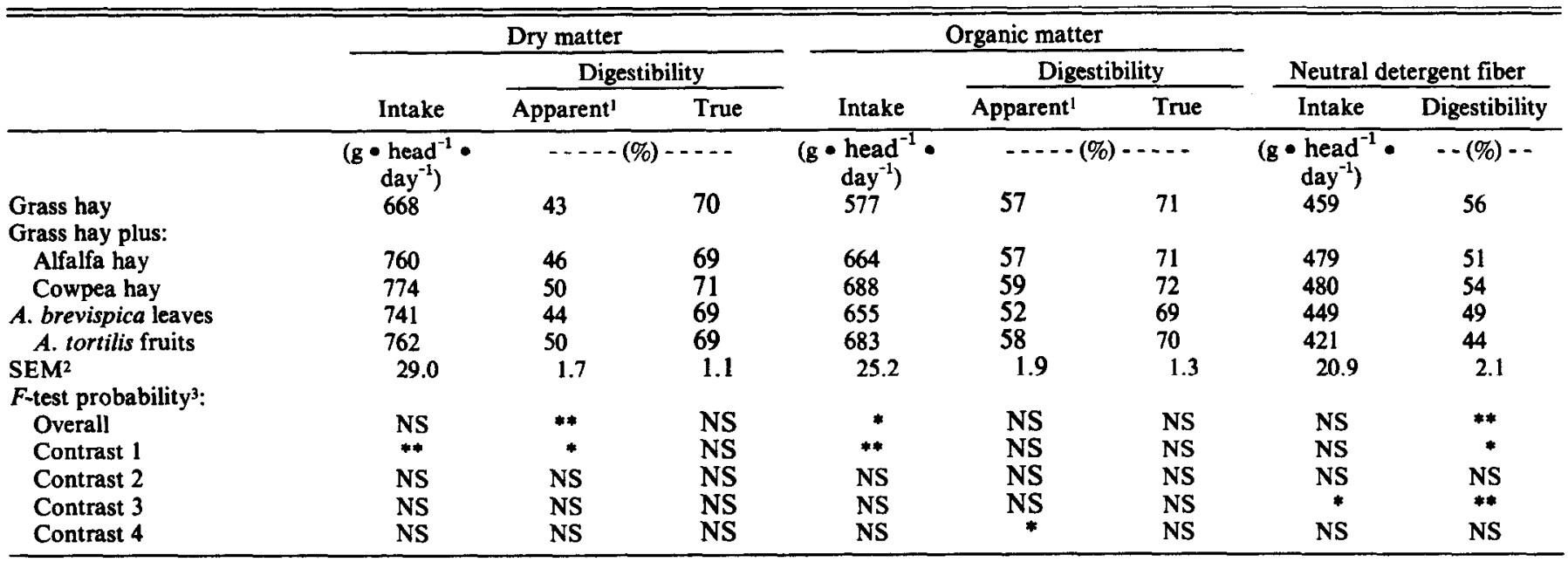

*,**Significant at the 0.05 and 0.01 levels, respectively.

'Calculated as [1-(fecal output/intake)] $\times 100$.

2SEM = standard error of the means based on 25 degrees of freedom.

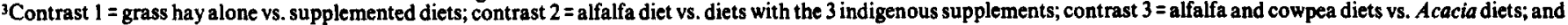
contrast $4=A$. brevispica diet vs. A. tortilis diet.

\section{Animals, Diets, and Experimental Designs Sheep Trials}

Thirty intact male Menz sheep (average age 7 months; average liveweight $17.7 \mathrm{~kg}$ ) were ranked according to weight and randomly allocated into 5 groups of 6 animals. Each group thus initially had the same average weight. Treatments included: (1) ad libitum access to the native grass hay (i.e., the base ration), or the base ration plus: (2) $345 \mathrm{~g} /$ day of alfalfa hay; (3) $387 \mathrm{~g} /$ day of cowpea hay; (4) $302 \mathrm{~g} /$ day of $A$. brevispica leaves; or (5) $368 \mathrm{~g} /$ day of $A$. tortilis fruits, all on an as-fed basis.

Each treatment diet was expected to provide sufficient nitrogen (N) and metabolizable energy (ME) for $50 \mathrm{~g}$ of liveweight gain $\bullet$ head $^{-1} \cdot$ day $^{-1}$. Sheep requirements were calculated using the factorial method with nutritional standards for temperate breeds (ARC 1980). It was assumed in these calculations that daily drymatter intake (DMI) would be $3 \%$ of liveweight in each supplemented treatment, supplements would be entirely consumed, trueDM digestibility of each diet would be $60 \%$, and true- $\mathrm{N}$ digestibilities would range from $85 \%$ for the Acacia L. diets to $90 \%$ for the non-tanniniferous diets (Tanner 1988, Woodward 1988).

Animals were fed individually. Supplements were weighed out daily and half was offered to each animal at 0800 and 1600 in troughs adjacent to those containing the grass hay. Refusals were also weighed and subsampled daily to provide a composited sample for each animal throughout the trial, and this composited sample was used for nutritional analysis. Animals had ad libitum access to water and salt block $(90 \% \mathrm{NaCl}, 4.4 \% \mathrm{P}, 5.2 \% \mathrm{Ca}$, and $0.4 \% \mathrm{Mg}$ on a DM basis).

The first experiment consisted of an 84-day growth trial with sheep held in individual pens. During this trial all animals were weighed initially and thereafter at weekly intervals following a night without food or water. The same animals on the same diets were then placed in metabolism crates for a 10-day adaptation period followed by a 10-day metabolism trial in which urine and feces were collected for each animal, using urine funnels and fecal bags. Fecal samples were frozen fresh while urine was preserved by adding $5 \mathrm{ml}$ of $95 \% \mathrm{H}_{2} \mathrm{SO}_{4}$.

\section{Calf Trial}

One hundred twenty-five nursing Boran calves (average age 3.5 months; average liveweight $37.4 \mathrm{~kg}$ ) were ranked according to weight and randomly allocated into 5 groups of 25 animals. Each group thus initially had the same average weight. Animals were individually fed supplements under a regime of simulated pastoral management. The control treatment consisted of: (i) restricted suckling with access to the same 2 quarters twice per day in the morning and evening (the other 2 quarters were milked out by hand after suckling and milk intake averaged $37 \%$ of production overall; D.L. Coppock, unpubl.); (ii) being herded for 6 hours/day with 4 hours/day used for grazing; (iii) being housed individually in small mud huts for 11 hours each night; and (iv) once-daily access to water in the afternoon. The other treatments consisted of the control condition plus: (1) $567 \mathrm{~g} /$ day of alfalfa hay; (2) $662 \mathrm{~g} / \mathrm{day}$ of cowpea hay; (3) $473 \mathrm{~g} /$ day of $A$. brevispica leaves; and (4) 616 $\mathrm{g} /$ day of $A$. tortilis fruits, all on an as-fed basis.

The supplements and grazing in each treatment were expected to provide sufficient $\mathrm{N}$ and $\mathrm{ME}$ for $150 \mathrm{~g}$ of liveweight gain/day. Calf requirements were calculated using the factorial method with nutritional standards for small temperate breeds (ARC 1980) given the moderate mature size of the local Boran (Cossins and Upton 1987). It was assumed that daily DMI of forage for nursing calves would be $2 \%$ of liveweight, supplements would be entirely consumed, and true digestibilities of DM and $\mathrm{N}$ for each diet would be the same as those anticipated for the sheep trial.

Supplements were offered at 1800 in plastic buckets to each calf overnight. Feeds and refusal samples were handled in the same manner described for the sheep trials. Local salt lick [41\% $\mathrm{NaCl}$ and minor quantities of other macro- and trace minerals ( $E$. Kabaija and D.A. Little, unpubl.)] was available to calves for 3 hours / day when they were held in corrals before and after grazing.

The 94-day growth trial was conducted during the height of the warm dry season (i.e. Jan. to March). Quantification of the composition and quality of calf grazing diets was based on biweekly observations of forage selection by 5 calves in which feeding time on each plant part and species was recorded (Woodward 1988). Using time-weighed profiles of diet composition, hand-plucked samples of selected forages were used for nutritional analyses and estimation of the mean value of nutrient concentrations in the grazed portion of the diet (Coppock et al. 1986b).

Calves were weighed initially and weekly thereafter following an 
Table 4. Nitrogen intake and digestibility for growing sheep ( $n=6$ per treatment) fed native grass hay with or without $A$ cacia, cowpes or alfalfa supplements during a 10-day metabolism trial.

\begin{tabular}{|c|c|c|c|c|c|}
\hline & \multicolumn{3}{|c|}{ Total nitrogen } & & \\
\hline & \multirow[b]{2}{*}{ Intake } & \multicolumn{2}{|c|}{ Digestibility } & \multicolumn{2}{|c|}{ NDF-Nitrogen } \\
\hline & & Apparent ${ }^{1}$ & True & Intake & Digestibility \\
\hline & $\begin{array}{l}\text { (gøhead } \\
\text { eday }^{-1} \text { ) }\end{array}$ & \multicolumn{2}{|c|}{$\ldots--(\%)-\ldots$} & $\begin{array}{l}\left(\text { g॰head }^{-1}\right. \\
\left.\text { day }^{-1}\right)\end{array}$ & $(\%)$ \\
\hline $\begin{array}{l}\text { Grass hay } \\
\text { Grass hay plus: }\end{array}$ & 8.3 & 39 & 91 & 4.3 & 83 \\
\hline Alfalfa hay & 12.1 & 51 & 93 & 4.9 & 82 \\
\hline Cowpea hay & 11.6 & 54 & 90 & 4.3 & 73 \\
\hline $\begin{array}{l}\text { A. brevispica } \\
\text { leaves }\end{array}$ & 12.9 & 53 & 88 & 5.7 & 72 \\
\hline A. tortilis fruits & 13.1 & 49 & 83 & 4.0 & 43 \\
\hline $\begin{array}{l}\text { SEM }^{2} \\
F \text {-test probability }{ }^{3} \text { : }\end{array}$ & 0.37 & 3.9 & 1.2 & 0.16 & 4.0 \\
\hline Overall & $* *$ & NS & $* *$ & $\neq *$ & ** \\
\hline Contrast 1 & ** & $* *$ & $*$ & $*$ & $* *$ \\
\hline Contrast 2 & NS & NS & $* *$ & NS & $* *$ \\
\hline Contrast 3 & $* *$ & NS & $* *$ & NS & $* *$ \\
\hline Contrast 4 & NS & NS & $*$ & $* *$ & $* *$ \\
\hline
\end{tabular}

*,**Significant at the 0.05 and 0.01 levels, respectively.

Calculated as [1-(fecal output/intake)] $\times 100$

2SEM $=$ standard error of the means based on 25 degrees of freedom.
2

${ }^{3}$ Contrast $1=$ grass hay alone vs. supplemented diets; contrast $2=$ alfalfa diet vs. diets with the 3 indigenous supplements; contrast $3=$ alfalfa and cowpea diets vs. Acacia diets; and contrast $4=A$. brevispica diet vs. $A$. tortilis diet.

overnight fast without supplements or water. Milk and water intake was estimated bi-weekly for each animal. Water intake was measured as consumption from plastic buckets, while milk intake was estimated using a weigh-suckle-weigh technique in the morning and evening.

Logistical constraints precluded the use of fecal collection to determine DM intake for the calves. Instead, intake was estimated indirectly for an average calf in each treatment from the daily $\mathbf{N}$ requirements for maintenance and observed growth using the factorial method described previously. The contribution of grazed DM to the diets was estimated by difference since the $\mathrm{N}$ content of the grazed portion of the diet and $\mathrm{N}$ intake of supplements and milk were known. Calculations used a milk $\mathrm{N}$ content of $0.53 \%$ (M.J. Nicholson, unpubl.), true-N digestibilities for diets from the sheep metabolism trial, and assumed a DMI of $2 \%$ of liveweight for estimating metabolic fecal $\mathbf{N}$.

\section{Chemical Analyses}

Feed samples were ground to pass a $1-\mathrm{mm}$ screen in a Wiley mill. These were analyzed for N (AOAC 1980), acid detergent fiber (ADF), neutral detergent fiber (NDF), acid detergent lignin (ADL), and in vitro dry-matter digestibility (IVDMD) (Goering and Van Soest 1970, Van Soest and Robertson 1980), and nitrogen in NDF (NDF-N) (Reed 1986). Phenolics were separated into 2 fractions. Concentrations of tannins and other phenolics soluble in aqueous acetone (soluble phenolics associated with cell solubles) were quantified as described by Reed et al. (1985), while concentrations of proanthocyanidin polymers insoluble in aqueous acetone or neutral detergent (insoluble proanthocyanidins associated with NDF) were estimated based on spectrophotometer absorbance readings at $550 \mathrm{~nm}$ of test solutions containing $5 \mathrm{mg}$ of NDF, n-butanol, and concentrated $\mathrm{HCl}$ and expressed as $\mathrm{A}_{550} / \mathrm{g} \mathrm{NDF}$ (Reed 1986).

Frozen feces were finely crushed using a mortar and pestle. Urinary and total fecal $\mathbf{N}$ was determined by kjeldahl analysis (AOAC 1980). Fecal $N$ was further divided into NDF-N and microbial plus endogenous- $N$ fractions by determination of fecal NDF-N and subtracting this from total N (Mason 1969). Retained $\mathrm{N}$ was calculated as the difference between $\mathrm{N}$ intake and $\mathrm{N}$ excreted.

\section{Statistics}

All trials employed stratified-random statistical designs and data were analyzed using the Statistical Analysis System (SAS 1987). In the sheep trials a one-way analysis of variance (ANOVA) was used to analyze treatment effects on intake and digestibility of DM, organic matter (OM), NDF, NDF-N, and $\mathrm{N}$ as well as $\mathrm{N}$ retention, average daily gain (ADG) and conversion efficiency of DMI into liveweight. Average daily gain was estimated for each animal using a linear regression of weight versus time. A one-way ANOVA with $\mathbf{N}$ intake as a covariate was used to assess $\mathbf{N}$ retention and losses.

In the calf trial a one-way ANOVA was used to analyze ADG and water intake [i.e., $\mathrm{ml} \bullet \mathrm{W}^{0.82}$, where $\mathrm{W}^{-0.82}$ is an empirical liveweight scalar relevant for water-intake studies (King 1983)], and milk intake per unit metabolic weight (i.e., $\mathrm{ml} \cdot \mathrm{W}^{-0.73}$; ARC 1980 ) was used as a covariate. Average daily gain was estimated for each animal using linear regression.

Single degree of freedom contrasts were used in all trials to compare response variables from: (1) the unsupplemented diet vs. the 4 supplemented diets; (2) the alfalfa diet vs. the cowpea and Acacia diets; (3) alfalfa and cowpea diets vs. the Acacia diets; and (4) the $A$. brevispica diet vs. the $A$. tortilis diet. All differences mentioned in this paper are significant at the $P<0.05$ probability level unless noted otherwise.

\section{Results}

\section{Forage Chemical Composition}

Compared to the supplements, basal components in all trials were lower in $\mathrm{N}$ content, higher in NDF and NDF-N, and lower in digestibility and content of soluble phenolics (Table 1). Differences among basal diets and supplements were less pronounced for ADL or insoluble proanthocyanidins, but $\boldsymbol{A}$. brevispica leaves were highest in these respects. Among supplements cowpea hay was lowest in N, and the Acacia materials were lower in NDF and ADF and higher in concentrations of phenolic compounds. Variation between browse materials in phenolic constituents was particularly apparent in the sheep trial, where $A$. tortilis fruits were higher in soluble phenolics while $A$. brevispica leaves were higher in insoluble proanthocyanidins. Between-trial variation in forage quality was most evident for alfalfa hay overall and for $A$. tortilis fruits in terms of phenolics (Table 1). Differences in $A$. tortilis fruits were probably a result of variation in time of collection in relation to ripening. Fruits for the sheep trial were collected relatively earlier, which is reflected in their higher levels of soluble phenolics. One consequence of ripening may be gradual shift from soluble to less soluble phenolics as a result of polymerization.

\section{Sheep Growth Trial}

On a DM basis, sheep consumed $91 \%$ of the $A$. tortilis fruits, $88 \%$ of the alfalfa or cowpea hay, and $78 \%$ of the $A$. brevispica leaves offered when averaged throughout the trial (Table 2). Intake of grass hay by all supplemented groups was lower $(P<0.01)$ compared to the control, which resulted from supplements replacing from 22 to $38 \%$ of the grass hay in the diets. This substitution led to no differences in total DMI. Acacia and cowpea supplements averaged $39 \%$ of total DMI, comparable to $38 \%$ for alfalfa. All supplemented diets increased $\mathrm{N}$ intake by an average $71 \% \mathrm{com}-$ pared to the control, and Acacia diets were higher in this regard than cowpea and alfalfa diets $(P<0.01)$. Growth rates and diet conversion efficiency for supplemented sheep were increased $(P<0.01)$ compared to the controls by an average of 74 and $54 \%$, respectively.

\section{Sheep Metabolism Trial}

Supplementation increased DMI, apparent DM digestibility, 
Table 5. Nitrogen losses and balance $\left(g \cdot\right.$ head $^{-1} \bullet$ day $\left.^{-1}\right)$ for growing sheep $(n=6$ per treatment) fed native grass hay with or without $A$ cacia, cowpea or alfalifa supplements during an 10-day metabolism trial.

\begin{tabular}{|c|c|c|c|c|c|c|}
\hline \multirow[b]{3}{*}{ Diets } & \multicolumn{4}{|c|}{ Nitrogen losses ${ }^{1}$} & & \\
\hline & \multirow[b]{2}{*}{ Urinary } & \multicolumn{3}{|c|}{ Fecal } & \multicolumn{2}{|c|}{ Nitrogen retention } \\
\hline & & Soluble & Insoluble & Total & Adjusted 1 & Absolute $^{2}$ \\
\hline & $\ldots \ldots \ldots$ & $\ldots \ldots$ & $\cdots(g \cdot h e$ & $-1)=--$ & $\ldots \ldots-\ldots$ & $\ldots \ldots-\ldots$ \\
\hline Grass hay & 2.4 & 5.5 & 1.0 & 6.5 & 2.7 & 1.7 \\
\hline \multicolumn{7}{|l|}{ Grass hay plus: } \\
\hline Alfalfa hay & 3.4 & 4.9 & 0.8 & 5.7 & 2.5 & 2.6 \\
\hline Cowpea hay & 3.3 & 4.1 & 1.2 & 5.3 & 3.0 & 3.0 \\
\hline A. brevispica leaves & 2.8 & 4.1 & 1.5 & 5.6 & 3.3 & 3.6 \\
\hline A. tortilis fruits & 2.0 & 4.0 & 2.1 & 6.1 & 3.5 & 4.0 \\
\hline SEM $^{3}$ & 0.20 & 0.47 & 0.16 & 0.45 & 0.18 & 0.40 \\
\hline \multicolumn{7}{|l|}{$F$-test probability4: } \\
\hline Overall & $*$ & NS & ** & NS & NS & $* *$ \\
\hline Contrast 1 & ** & NS & ** & NS & NS & $* *$ \\
\hline Contrast 2 & $*$ & NS & $* *$ & NS & NS & $*$ \\
\hline Contrast 3 & ** & NS & $* *$ & NS & NS & $*$ \\
\hline Contrast 4 & * & NS & $* *$ & NS & NS & NS \\
\hline
\end{tabular}

*,* Significant at the 0.05 and 0.01 levels, respectively.

tTabulated entries based on a common nitrogen intake of $11.6 \mathrm{~g} \bullet \mathrm{head}^{-1} \bullet \mathrm{day}^{-1}$ in the covariate analysis.

${ }^{2}$ Calculated by difference and analyzed without a covariate.

3SEM = standard error of the means based on 25 degrees of freedom.

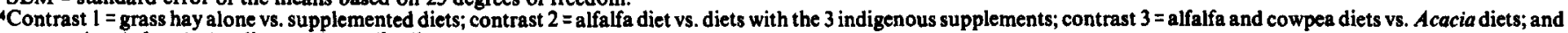
contrast $4=A$. brevispica diet vs. $A$. tortilis diet.

OM intake, and NDF digestibility (Table 3). Intake and digestibility of NDF were higher with cowpea and alfalfa diets compared to Acacia diets. The $A$. brevispica diet was lower than the $A$. tortilis diet in apparent $\mathrm{OM}$ digestibility.

Total $\mathrm{N}$ intake was increased by an average of $50 \%$ in supplemented groups compared to the control (Table 4). Intakes of NDF-N ranged from $31 \%$ of total $\mathrm{N}$ intake for the $A$. tortilis diet to $52 \%$ for the control diet. The $A$. tortilis diet was lower than the $A$. brevispica diet in true digestibility of total N or NDF-N, which may have been due to the high content of soluble phenolics in the $A$. tortilis fruits (Table 1).

In absolute terms, all supplemented groups had higher $(P<0.01)$ rates of $\mathbf{N}$ retention than control animals, and $\mathrm{N}$ retention for sheep on alfalfa was lower compared to those on indigenous supplements (Table 5). However, when $\mathrm{N}$ intakes were adjusted to a common level in the covariate analysis, $\mathrm{N}$ retention was similar across treatments. Supplementation increased $(P<0.01)$ output of urinary and fecal-insoluble $\mathrm{N}$ compared to controls. The Acacia diets differed $(P<0.01)$ from alfalfa and cowpea diets by having lower or higher excretion for urinary and fecal-insoluble $\mathrm{N}$, respectively. The $A$. tortilis diet was the most distinctive in this regard (Table 5).

\section{Calf Growth Trial}

On a DM basis, the calves consumed about $86 \%$ of the alfalfa hay or A. tortilis fruits and $71 \%$ of the cowpea hay or A. brevispica leaves offered throughout the trial (Table 6). Milk intake did account for some differences in calf growth (6\%) or water intake (1\%) in the covariate analyses, but results indicated that milk intake was adequately standardized among treatments. Nitrogen intake from supplements ranged from $8.1 \mathrm{~g} \cdot$ head $^{-1}{\text {. } \text { day }^{-1}}^{-1}(A$. brevispica) to $14.8 \mathrm{~g} \cdot$ head $^{-1} \cdot$ day $^{-1}$ (alfalfa). Supplementation increased $(P<0.01)$ calf growth rates by 44 to $95 \%$ compared to the control, and the alfalfa diet elicited higher growth rates than diets with the indigenous legumes $(P<0.01)$. Supplementation increased $(P<0.01)$ water intake overall compared to the control group, with smaller differences evident among supplemented groups (Table 6).

On average, the supplements probably comprised a larger proportion of the total diet of the calves compared to that observed for the sheep. For the control calves the factorial analysis indicated that the milk intake of $380 \mathrm{ml} \bullet$ head $^{-1} \bullet$ day $^{-1}$ contributed $14 \%$ of
Table 6. Intakes of milk, forage (dry-matter basis), and water and growth rates for nursing Boran calves $(n=22$ to 25 per treatment) under simulated pastoral management with or without $A$ cacia, cowpen or alfalia supplements during a 94-day growth trial.

\begin{tabular}{|c|c|c|c|c|}
\hline & $\begin{array}{l}\text { Supplement } \\
\text { intake }\end{array}$ & $\begin{array}{c}\text { Milk } \\
\text { intake }\end{array}$ & $\begin{array}{l}\text { Water } \\
\text { intake }\end{array}$ & $\begin{array}{l}\text { Growth } \\
\text { rate }\end{array}$ \\
\hline & $\begin{array}{c}\left(g_{0} \cdot h_{\text {head }}^{-1}\right. \\
\left.\text { day }^{-1}\right)\end{array}$ & $\left(\mathrm{ml} \cdot \mathrm{W}^{-0.73}\right)$ & $\left(\mathrm{ml} \cdot \mathrm{W}^{-0.82}\right)$ & $\begin{array}{c}\left(\mathrm{g}^{\circ} \text { head }^{-1}\right. \\
\left.\text { day }^{-1}\right)\end{array}$ \\
\hline Grass hay & 0 & 25 & 112 & 81 \\
\hline \multicolumn{5}{|l|}{ Grass hay plus: } \\
\hline Alfalfa hay & 438 & 25 & 138 & 158 \\
\hline Cowpea hay & 423 & 25 & 112 & 107 \\
\hline $\begin{array}{l}\text { A. brevispica } \\
\text { leaves }\end{array}$ & 300 & 25 & 134 & 117 \\
\hline A. tortilis fruits & 463 & 24 & 130 & 137 \\
\hline SEM $^{1}$ & - & - & 4.7 & 8.9 \\
\hline \multicolumn{5}{|l|}{$\begin{array}{l}F \text {-test } \\
\text { probability2: }\end{array}$} \\
\hline Overall & - & - & $* *$ & $* *$ \\
\hline Contrast 1 & - & - & ** & ** \\
\hline Contrast 2 & - & - & $* *$ & $* *$ \\
\hline Contrast 3 & - & - & NS & NS \\
\hline Contrast 4 & - & - & $*$ & NS \\
\hline
\end{tabular}

*,**:Significant at the 0.05 and 0.01 levels, respectively.

'SEM = standard error of the means based on either 396 or 116 degrees of freedom for water intake or growth rate, respectively.

${ }^{2}$ Contrast 1 = grass hay alone vs. supplemented diets; contrast 2 = alfalfa diet vs. diets with the 3 indigenous supplements; contrast $3=$ alfalfa and cowpea diets vs. Acacia diets; and contrast $4=A$. brevispica diet vs. $A$. tortilis diet.

the total dietary $\mathrm{N}$ requirements of $14.8 \mathrm{~g} \bullet$ head $^{-1} \bullet$ day $^{-1}$, with the remainder from about $1.3 \mathrm{~kg} \mathrm{DM}$ of daily grazing. Milk provided from 10 to $12 \%$ of the $\mathrm{N}$ requirements for calves in the supplemented groups, while the legumes provided from $46 \%$ (A. brevispica diet) to $55 \%$ ( $A$. tortilis and cowpea diets) and $78 \%$ (alfalfa diet). Averaged across supplemented groups the contribution of milk, supplements, and grazing to $\mathrm{N}$ requirements may have been 11,58 , and $31 \%$, respectively. Compared to the control group, supplements may have reduced grazing intake on the order of $40 \%$ (A. brevispica diet), $45 \%$ (A. tortilis diet), 55\% (cowpea diet), and $80 \%$ (alfalfa diet). Total DMI (excluding milk) for the supplemented groups may have been reduced by $12 \%$ ( $A$. tortilis diet $)$ to 
$50 \%$ (alfalfa diet). Thus, it is speculated that compared to the sheep, the legumes not only replaced more of the base diet for the calves but also contributed to a lower total DMI. This was because the grazing intake was more limiting to the calves than the grass hay offered to sheep in terms of availability (due to forage distribution and restricted feeding time) and quality especially IVDMD; Table 1).

\section{Between-Trial Variation}

Despite the use of nutritional standards for temperate breeds (ARC 1980), other assumptions, and sources of experimental error, the targeted growth rate from supplementation of sheep ( 50 $\left.\mathrm{g} \cdot \mathrm{head}^{-1} \cdot \mathrm{day}^{-1}\right)$ was achieved in all treatments, while that for the calves $\left(150 \mathrm{~g} \bullet \mathrm{head}^{-1} \cdot \mathrm{day}^{-1}\right)$ was not in 3 of 4 treatments, even with the contribution from milk. The less accurate transferability of guidelines for the calves may have been largely due to differences in $\mathrm{N}$ or $\mathrm{ME}$ requirements, but it may have also been related to the lower relative intake of some supplements by calves compared to the sheep and the low IVDMD of grazing.

Compared to the sheep growth trial, there was also higher variability in growth among supplemented calf groups. This was most likely due to between-trial variation in diet quality. The lower nutritive value of grazing plus the larger variability in quality of supplements in the calf trial served to spread treatment response to a greater degree. For example, compared to the sheep, the relatively greater response of calves to alfalfa, or their smaller response to cowpea, reflected larger differences in nutritive value between these materials (Table 1). Similarly, the greater relative response of calves to $A$. tortilis diets compared to sheep was probably related to the lower concentration of soluble phenolics in the fruits for the calves, which may have had the greatest influence on $\mathrm{N}$ digestibility. In sum, these results are interpreted to show that high variability occurs in the nutritive value of these legumes and that it is difficult to precisely predict animal response to supplementation under these conditions.

\section{Discussion and Conclusions}

Our work demonstrated that these $A$ cacia and cowpea materials are suitable protein sources in terms of intake and growth responses. This has been previously documented for the Acacia forages. Tanner et al. (1990) found sheep to consume all the $A$. tortilis fruits on offer and to grow at the same rate as sheep fed oilseed meal [Guizotia abyssinica (L.f.) Cass.] when both were offered as isonitrogenous protein supplements to maize stover (Zea mays L.). In addition, there were also no differences between these 2 diets in terms of digestibility of DM or OM. Woodward (1988) reported that sheep and goats under confinement consumed over $90 \%$ of $A$. brevispica leaves on offer, and had diet digestibilities of DM and OM similar to those for animals fed vetch (Vicia dasycarpa Tenore) when offered as isonitrogenous supplements to teff [ Eragrostis tef (Zucc.) Trotter] straw. Field observations have also indicated a high acceptance of $A$. tortilis fruits by sheep and goats (Pratt and Gwynne 1977, Coppock et al. 1986a) and $A$. brevispica leaves by sheep, goats, and camels (Woodward 1988).

Despite the positive responses of sheep and calves in terms of legume intake and increased growth, the role of these legumes as supplements, in a strict sense, remains open to debate. One hypothesis was that legume feeding should increase intake and digestibility of fiber, thereby improving the efficiency of use of the base component of the diet. When the control group was compared vs. all supplemented diets in the sheep metabolism trial, no differences were observed in NDF intake, and the legume diets appeared to reduce NDF digestibility. There is a problem, however, with interpretation of NDF digestibility of the Acacia diets. This is because tannins complex with other dietary components and appear as fecal NDF, which biases estimation of true-NDF digestibility (Reed 1986). Considering the high proportion of legumes in sheep and calf diets, it is likely that the most important effect of legumes on improved performance was because of their absolute contributions of $\mathrm{N}$ and $\mathrm{ME}$.

The legumes had varied effects on utilization of dietary protein and this was probably influenced by the different types and concentrations of phenolics. The nutritional effects of these compounds are diverse. In many cases phenolics have negative effects on forage palatibility and diet digestibility (Hatfield 1970, Bate-Smith 1973, Reed et al. 1990). However, phenolics may also improve $\mathrm{N}$ retention (Egan and Ulyatt 1980, Barry and Manley 1984).

Soluble phenolics include tannins which may form indigestible complexes with nutrients and inhibit enzymes (Reed et al. 1985). Many browse species also contain insoluble proanthocyanidins which may complex with protein and carbohydrate and elevate the content of NDF and NDF-N (Reed 1986). Our results indicate that the $A$. tortilis fruits had the greatest effect on $\mathrm{N}$ digestion and this was probably due to their high content of soluble phenolics.

We did not examine differential digestibility of the pods and seeds that comprised the $A$. tortilis fruits, but Tanner (1988) found that $54 \%$ of $A$. tortilis seeds passed undigested through his sheep. This was in contrast to much lower passage rates (4 to $16 \%$ ) for seeds of 3 other $A$ cacia species he tested. The undigested seeds of $A$. tortilis constituted a significant portion of the diet in the study by Tanner (1988); they represented 19 and $31 \%$, respectively, of the intake of $\mathrm{DM}$ and $\mathrm{N}$ of the fruits and 6 and $11 \%$, respectively of the total dietary intake of DM and $\mathrm{N}$.

Tanner (1988) used our assays for phenolics as well as high performance liquid chromatography and thin layer chromatography to isolate proanthocyanidins in $A$. tortilis fruits. Soluble phenolics in the seeds consisted of prodelphidins of high molecular weight. These compounds may increase the resistance of $A$. tortilis seeds to digestion and decrease protein digestibility.

Previous research on the soluble phenolics and insoluble proanthocyanidins in $A$. brevispica leaves indicates that the phenolics have little effect on inhibition of cellulase and protein precipitation (Reed et al. 1985). The soluble phenolic fraction has a low content of proanthocyanidins (Mueller-Harvey et al. 1987).

In accordance with work by Nastis and Malechek (1981), Woodward (1988), Nunez-Hernandez et al. (1989), Reed et al. (1990), and Tanner et al. (1990), our results indicate that tanniniferous forages can be suitable protein sources as long as the negative effect of tannins on increasing output of fecal $\mathrm{N}$ is less than their positive effect of reducing urinary-N loss. In contrast to this perspective, however, work with native American shrubs indicates that forages high in tannin content reduced $\mathrm{N}$ retention in goats more by depressing intake rather than through influences on $\mathrm{N}$ digestion (Holechek et al. 1990).

Nunez-Hernandez et al. (1989) concluded from their studies of temperate browse that moderate intakes (30\% of DM) of most materials tested resulted in efficiencies of $\mathbf{N}$ assimilation similar to those of animals on diets supplemented with alfalfa. Our work supports a similar view for these tropical browses, as even high (40 to $60 \%$ ) proportions of these materials in calf diets apparently had no negative effects.

Recommended use of tanniniferous forages is complicated by effects of stage of maturity (Nastis and Malechek 1981), local environment (Barry and Forss 1983), and drying procedures (Price et al. 1979) on phenolic content. While caution may be appropriate, we found nothing to preclude recommendation of the indigenous forages tested here.

Although the legumes examined in this research are suitable in terms of nutritional value, their implication in improved feeding systems for calves also depends on the productivity and distribu- 
tion of plants because this determines the labor needed for forage collection. Calf feeding among the Boran is traditionally somewhat intensive, as nursing calves obtain a large proportion of forage as standing grass collected and hand fed by women (Mulugeta 1990). Grass collection is reportedly most difficult in dry seasons when the women have to spend more time searching for forages of sufficient quality, and those labor constraints may limit the amount of forage offered to calves (Mulugeta 1990). Improved feeding systems should thus raise the level of calf nutrition, but without a large increase in labor.

While there has been no tradition among the Boran of collecting and storing calf forage for the dry season, some success has been achieved in extending concepts of storing grass hay after the long rains (when seasonal labor demands are lower) and collecting $A$. tortilis fruits during dry periods (Mulugeta 1990). Changing attitudes of the Boran towards more intensified use of resources may be due in part to increasing population pressure and competition (Menwyelet 1990).

Calves consumed from 300 to $460 \mathrm{~g} \cdot$ head $^{-1} \cdot$ day $^{-1}$ of the legumes on a DM basis, which translates into 27 to $41 \mathrm{~kg} \mathrm{DM}$ per calf for 90 days at the height of the dry season. For many families, however, the labor required to collect this much material can be prohibitive. Instead of legumes being used to augment calf diets based on sparse, poor-quality grazing or cut-and-carry forage found in dry periods, a more appropriate method could be to use legumes with the grass hay made earlier in the year. Grass hay made by the Boran in extension trials has a higher $\mathbf{N}$ content and IVDMD compared to standing grass in the dry season (Mulugeta 1990). For example, using legumes to slightly improve a hay-based diet, offered at $1 \mathrm{~kg} \cdot$ head $^{-1} \cdot$ day $^{-1}$, from 6 to $8 \%$ crude protein on a DM basis would require from 30 to $45 \%$ less of the legumes compared to the amounts consumed by calves in this research (D.L. Coppock, unpubl.). This represents a large labor savings, which makes effective use of legumes more likely and illustrates the interdependency of forage interventions. Studies have indicated that the legumes average 2.5 -times as expensive as grass hay in terms of seasonal labor costs, so the legume input needs to be minimized (Mulugeta 1990).

Acacia tortilis fruits are produced in dry seasons when forage is most needed. This species is recognized as drought tolerant and a key forage stabilizer in African pastoral systems (Coughenour et al. 1985, Coppock et al. 1986a, Gates and Brown 1988). Acacia tortilis should be promoted in range improvement programs. Cowpea should also be promoted, but first for its seed to diversify human diets and second as fodder for supplementing livestock (Yohannes 1989). Cowpea should also serve as a useful riskaversion crop with cereals (Hulet and Gosseye 1986). Acacia brevispica is the most difficult of these plants to use because of a low standing crop of leaves per shrub ( 1 to $2 \mathrm{~kg} \mathrm{DM}$; A. Woodward, unpubl.) and prickly leaf rachii that make harvest of large quantities difficult by hand. However, this is an invading species that has formed thickets at higher elevations (Tamene 1990). Boran who reside in these areas could efficiently collect leaves if this was promoted, which could help control $A$. brevispica.

Improved feeding management of calves in this system will also depend on more water development to allow calves greater intake of improved feeding packages (D.L. Coppock, unpubl.). To be successful, interventions that involve planting forages (e.g., $A$, tortilis trees) must take advantage of situations where communal land tenure has been replaced by regulated access. This is becoming more prevalent on the Borana Plateau because of population pressure (Menwyelet 1990).

\section{Literature Cited}

AOAC. 1980. Official methods of analysis (13th Ed.). Association of Official Analytical Chemists. Washington, D.C.
ARC. 1980. The nutrient requirements of ruminant livestock. Commonwealth Agr. Bureaux, Slough.

Barry, T.N., and D.A. Forss. 1983. The condensed tannin content of vegetative Lotus pedunculatus, its regulation by fertilizer application and effect upon protein solubility. J. Sci. Food Agr. 34:1047-1056.

Barry, T.N., and T.R. Manley. 1984. The role of condensed tannins in the nutritional value of Lotus pedunculatus for sheep. 2. Quantitative digestion of carbohydrates and proteins. Brit. J. Nutr. 55:123-137.

Bate-Smith, E.C. 1973. Haemanalysis of tannins: The concept of relative astringency. Phytochem. 12:907-912.

Coppock, D.L., J.E. Ellis, and D.M. Swift. 1986a. Livestock feeding ecology and resource utilization in a nomadic pastoral ecosystem. $J$. Appl. Ecol. 23:573-584.

Coppock, D.L., D.M. Swift, and J.E. Ellis. 1986b. Seasonal nutritional characteristics of livestock diets in a nomadic pastoral ecosystem. $\mathbf{J}$ Appl. Ecol. 23:585-596.

Cossins, N.J., and M. Upton. 1987. The Borana pastoral system of southern Ethiopia. Agr. Systems 25:199-218.

Coughenour, M.B., J.E. Ellis, D.M. Swift, D.L. Coppock, K. Galvin, J.T. McCabe, and T.C. Hart. 1985. Energy extraction and use in a nomadic pastoral ecosystem. Science 230:619-624.

Donaldson, T.J. 1986. Pastoralism and drought: A case study of the Borana of southern Ethiopia. Master's Thesis, Reading Univ.

Egan, A.R., and M.J. Ulyatt. 1980. Quantitative digestion of fresh herbage by sheep VI. Utilization of nitrogen in five herbages. J. Agr. Sci., (Camb). 94:47-56.

Gates, P.J., and K. Brown. 1988. Acacia tortilis and Prosopis cineraria: Leguminous trees for arid areas. Outluok Agr. 17:61-64.

Goering, H.K., and P.J. Van Soest. 1970. Forage fiber analysis. ARS, USDA Agr. Handb. 379.

Hatfield, E.E. 1970. Achieving the potential of high quality dietary protein for ruminants. Feedstuffs 42:23-28.

Holechek, J.L., A.V. Munshikpu, I. Saiwana, G. Nunez-Hernandez, R. Valdez, J.D. Wallace, and M. Cardenas. 1990. Influences of six shrub diets varying in phenol content on intake and nitrogen retention by goats. Trop. Grassl. 24:93-98.

Hulet, H., and P. Gosseye. 1986. Effect of intercropping cowpea on drymatter and grain yield of millet in the semi-arid zone of Mali, pp. 379-396. In: 1. Haque, S. Jutzi, and P.J.H. Neate (ed.). Proc. workshop on potentials of forage legumes in farming systems of sub-Saharan Africa. International Livestock Centre for Africa, Addis Ababa.

Jahnke, H.E. 1982. Livestock production systems and livestock development in tropical Africa. Kieler Wissenschaftsverlag Vauk, Kiel.

King, J.M. 1983. Livestock water necds in pastoral Africa in relation to climate and forage. Res. Rep. 7. International Livestock Center for Africa, Addis Ababa.

Mason, V.C. 1969. Some observations on the distribution and origin of nitrogen in sheep faeces. J. Agr. Sci., (Camb). 73:99-111.

Menwyelet, A. 1990. Ecology of calf pastures and supplementary feeding by Borana pastoralists of southern Ethiopia. Master's thesis, Colorado State Univ., Fort Collins

Mueller-Harvey, I., J.D. Reed, and R.D. Hartley. 1987. Characteristics of phenolic compounds, including flavanoids and tannins, of ten Ethiopian browse species by high-performance liquid chromatography. J. Sci. Food Agr. 39:1-14.

Mulugeta, A. Borana cattle herds: Productivity, constraints, and possible interventions. Master's thesis, Colorado State Univ., Fort Collins.

Nastis, A.S., and J.C. Malechek. 1981. Digestion and utilization of nutrients in oak browse by goats. J. Anim. Sci. 53:283-290.

Nunez-Hernandez, G., J.L. Holechek, J.D. Wallace, M.L. Galyean, A. Tembo, R. Valdez, and M. Cardenas. 1989. Influence of native shrubs on nutritional status of goats: Nitrogen retention. J. Range Manage. 42:228-232

Pratt, D.J., and M.D. Gwynne (ed.). 1977. Rangeland management and ecology in East Africa. Hodder and Stoughton Co., London.

Price, J.L., A.M. Stromberg, and L.C. Butler. 1979. Tannin content as a function of grain maturity and drying conditions in several varieties of Sorghum bicolor. J. Agr. Food Chem. 57:1270-1274

Reed, J.D. 1986. Relationships among soluble phenolics, insoluble proanthocyanidins and fiber in East African browse species. J. Range Manage. 39:5-7.

Reed, J.D., P.J. Horvath, M.S. Allen, and P.J. Van Soest. 1985. Gravimetric determination of soluble phenolics including tannins from leaves by precipitation with trivalent ytterbium. J. Sci. Food Agr. 36:255-261. 
Reed, J.D., H. Soller, and A. Woodward. 1990. Fodder tree and straw diets for sheep: Intake, growth, digestibility and the effects of phenolics on nitrogen utilization. Anim. Feed Sci. Tech. 30:39-50.

Robbins, C.T., T.A. Hanley, A.E. Hagerman, O. Hjeljord, D.L. Baker, C.C. Schwartz, and W.W. Mautz. 1987. Role of tannins in defending plants against ruminants: Reduction in protein availability. Ecol. 68:98-107.

SAS. 1987. SAS/STAT ${ }^{\text {TM }}$ Guide for personal computers, 6 ed. Statistical Analysis System Institute, Inc., Cary, N.C.

Tamene, Y. 1990. Population dynamics of the problem shrubs Acacia drepanolobium and Acacia brevispica in the southern rangelands of Ethiopia. Master's Thesis, Univ. of New South Wales.

Tanner, J.C. 1988. Acacia fruit supplementation of maize stover diets fed to sheep. Master's thesis, Reading Univ.
Tanner, J.C., J.D. Reed, and E. Owen. 1990. The nutritive value of fruits (pods with seeds) from 4 Acacia spp. compared with extracted noug (Guizotia abyssinica) meal as supplments to maize stover for Ethiopian highland sheep. Anim. Prod. 51:127-134.

Van Soest, P.J., and J.B. Robertson. 1980. Systems of analysis for evaluating fibrous feeds, p. 49-60. In: W.J. Pigdan, C.C. Balch, and M. Graham (ed.). Proc. workshop on standardization of analytical methodology for feeds. IDRC, Ottawa, Canada.

Woodward, A. 1988. Chemical composition of browse in relation to relative consumption of species and nitrogen metabolism of livestock in southern Ethiopia. Ph.D. Thesis, Cornell Univ., Ithaca, New York.

Yohannes, A. 1989. Introducing tropical legumes into the southern rangelands of Ethiopia. Master's Thesis, Univ. of New South Wales. 